\title{
Novel KRIT1/CCM1 mutation in a patient with retinal cavernous hemangioma and cerebral cavernous malformation
}

\author{
Shantan Reddy • Michael B. Gorin • \\ Tara A. McCannel • Irena Tsui • Bradley R. Straatsma
}

Received: 31 December 2009 /Revised: 19 January 2010 / Accepted: 4 February 2010 / Published online: 20 March 2010

(C) The Author(s) 2010. This article is published with open access at Springerlink.com

\begin{abstract}
Backround Retinal cavernous hemangiomas are rare vascular anomalies, and can be associated with cerebral cavernous malformations (CCM). Distinct mutations have been reported in patients who have both CCMs and retinal cavernous hemangiomas.

Methods Fluorescein angiography, spectral domain optical coherence tomography, and genetic testing were performed on a patient with a retinal cavernous hemangioma and a CCM.

Results Our patient was heterozygous in the KRIT1/CCM1 gene for a frameshift mutation, c.1088delC. This would be predicted to result in premature protein termination.

Discussion We have identified a novel mutation in the KRIT1/CCM1 gene in a patient with both CCM and retinal cavernous hemangioma. We hypothesize that the occurrence of retinal cavernous hemangiomas and CCMs is underlaid by a common mechanism present in the KRIT1/CCM1 gene.
\end{abstract}

The authors have no financial interest in the material presented in this manuscript.

\footnotetext{
S. Reddy $(\bowtie)$

NYU Langone Medical Center,

530 First Ave, suite 3B,

New York, NY 10016, USA

e-mail: reddys02@gmail.com
}

M. B. Gorin - T. A. McCannel - I. Tsui • B. R. Straatsma Jules Stein Eye Institute, University of California, Los Angeles, CA, USA
Keywords Cerebral cavernous malformation · KRIT1 . Mutation $\cdot$ Retinal cavernous hemangioma

\section{Introduction}

Cerebral cavernous malformations (CCMs) are congenital vascular anomalies of the brain that can cause significant neurological disabilities. Similar vascular anomalies can also occur in the retina, and are referred to as retinal cavernous hemangiomas. Retinal cavernous hemangiomas are rare, and are associated with CCMs in approximately $5 \%$ of familial cases [1]. Distinct mutations have been reported in patients who have both CCMs and retinal cavernous hemangiomas [1-3]. We report what is, to our knowledge, a novel frameshift mutation in KRIT1(Krev interaction trapped-1)/CCM1) gene which was associated with a retinal cavernous hemangioma and a CCM.

\section{Methods and results}

An asymptomatic 30-year-old woman was referred for evaluation of a retinal mass in her right eye. Visual acuity was 20/20 in her right eye and 20/15 in her left eye. External, pupil, motility and anterior segment examinations were unremarkable. Fundus examination of the right eye revealed an elevated, dark red macular lesion with multiple saccular aneurysms (Fig. 1a). Fluorescein angiography showed a mass with hyperfluorescent areas and inferior blockage hypofluorescence consistent with a retinal 
Fig. 1 a Color photograph of the right eye illustrating a retinal cavernous hemangioma. b Fluorescein angiography of the right eye illustrating hyperfluorescent lesions with inferior blockage hypofluorescence
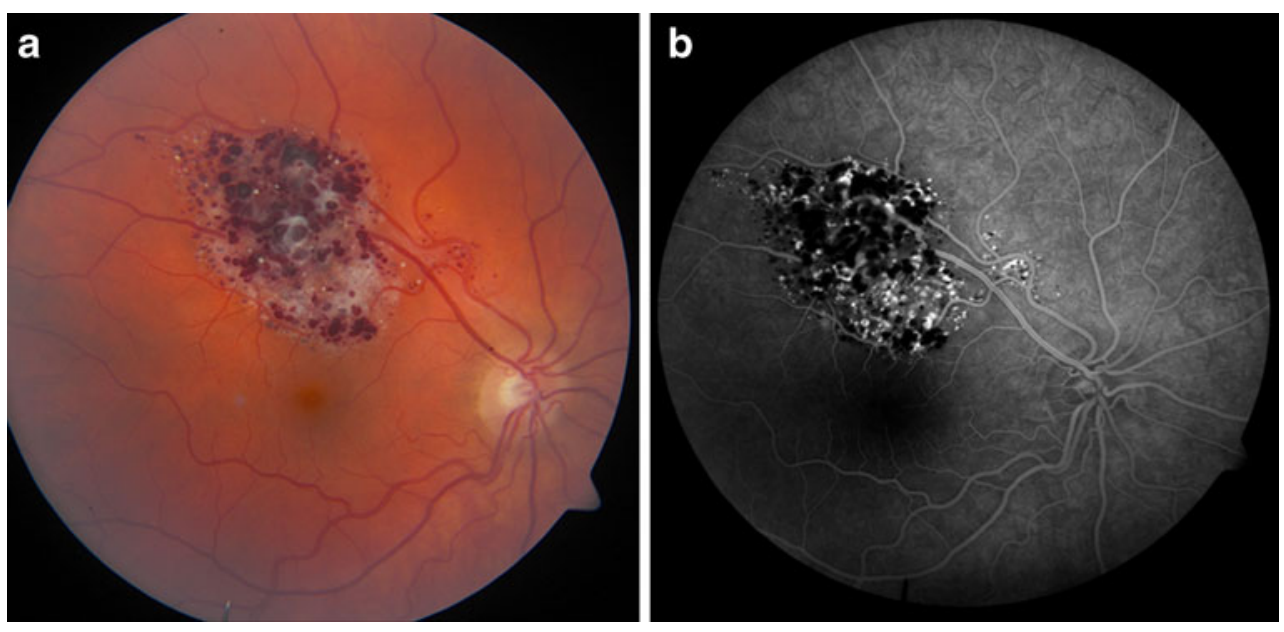

cavernous hemangioma (Fig. 1b). Fundus examination of the left eye was unremarkable. A CCM was present on cerebral imaging. Family history, based on self-reporting and medical records, revealed CCMs in seven of her family members, which included most of her mother' brothers and sister. Her mother and grandmother also had a retinal cavernous hemangioma in association with a CCM (Fig. 2). Genetic evaluation of our patient, using genomic DNA extracted from our patient's blood cells, involved sequencing of the full coding regions of all coding exons (1-16) of the KRIT1/CCM1gene as well as approximately 50 flanking bases. The patient was heterozygous in the KRIT1/CCM1 gene for a frameshift mutation, c.1088delC. This would be predicted to result in premature protein termination. The other family members were not accessible for clinical evaluation and DNA sampling for confirmation.

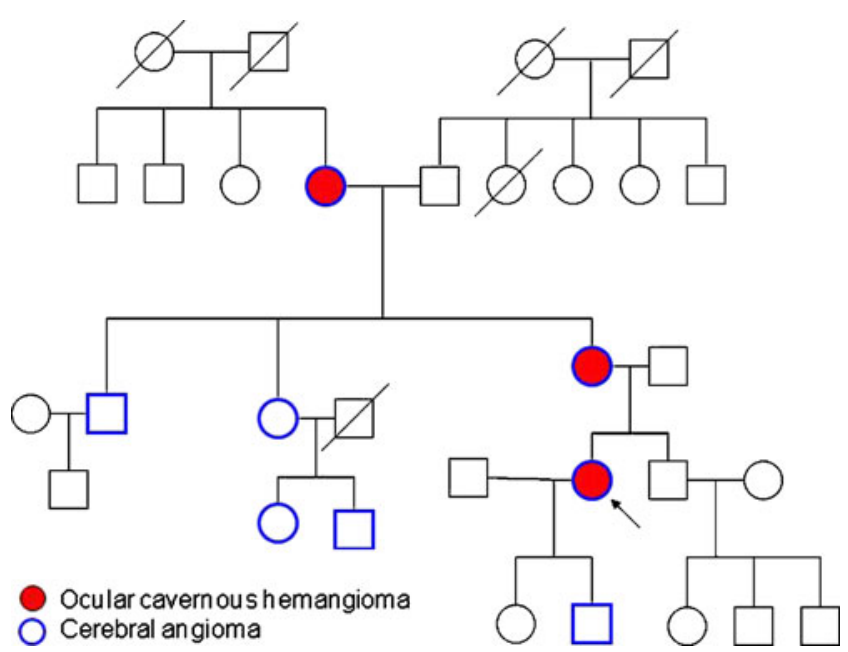

Fig. 2 A family tree illustrating which family members were affected by either a cerebral cavernous hemangioma, a retinal cavernous hemangioma, or both tumors. (The arrow designates the patient in our report)

\section{Discussion}

CCM can occur in either a sporadic or familial form. Familial CCMs show autosomal dominant inheritance, and may be associated with retinal cavernous hemangiomas [4]. A large deletion of the MGC4607 gene, a de novo deletion of the PDCD10 gene and three different mutations in the KRIT1/CCM1 gene have been identified in patients with both CCM and retinal cavernous hemangioma [1-3]. We have identified a novel mutation in the KRIT1/CCM1 gene in this patient with both $\mathrm{CCM}$ and retinal cavernous hemangioma.

The KRIT1/CCM1 gene encodes a protein that affects endothelial cell structure and function, and strong labeling of KRIT1 expression has been detected in both the brain and retina [5, 6]. Given our results in conjunction with three previously reported and different mutations in the KRIT1/CCM1 region, it is reasonable to hypothesize that the occurrence of retinal cavernous hemangiomas and $\mathrm{CCMs}$ are underlaid by a common mechanism present in this gene. All patients with a retinal cavernous hemangioma should undergo some type of cerebral imaging, (e.g. MRI or CT scan) to determine the presence of a CCM. If a patient is found to have both lesions, it is reasonable to perform a genetic evaluation from patient's blood cells to sequence the KRIT1/CCM1 gene. However, genetic diagnostics alone in a patient who presents with a retinal cavernous hemangioma is not a substitute for the neurologic and systemic workup that is required, since the condition is genetically heterogeneous. Though genetic results to date have no implication with regard to health or prognosis, the demonstration of a causative mutation in the KRIT1/CCM1 gene does provide greater certainty of the diagnosis, allows us to better justify future screening for the development of new lesions, and contributes to the genetic counseling and preventive care of at-risk family members. 
Open Access This article is distributed under the terms of the Creative Commons Attribution Noncommercial License which permits any noncommercial use, distribution, and reproduction in any medium, provided the original author(s) and source are credited.

\section{References}

1. Labauge P, Krivosic V, Denier C, Tournier-Lasserve E, Gaudric A (2006) Frequency of retinal cavernomas in 60 patients with familial cerebral cavernomas: a clinical and genetic study. Arch Ophthalmol 124:885-886

2. Couteulx SL, Brezin AP, Fontaine B, Tournier-Lasserve E, Labauge P (2002) A novel KRIT1/CCM1 truncating mutation in a patient with cerebral and retinal cavernous angiomas. Arch Ophthalmol 120:217-218
3. Kitzmann AS, Pulido JS, Ferber MJ, Highsmith WE, BabovicVuksanovic D (2006) A splice site mutation in CCM1/KRIT1 is associated with retinal and cerebral cavernous hemangioma. Ophthalmic Genet 27:157-159

4. Sarraf D, Payne AM, Kitchen ND, Sehmi KS, Downes SM, Bird AC (2000) Familial cavernous hemangioma. An expanding ocular spectrum. Arch Ophthalmol 118:969-973

5. Denier C, Gasc JM, Chapon F, Domenga V, Lescoat C, Joutel A, Tournier-Lasserve E (2002) KRIT1/cerebral cavernous malformation $1 \mathrm{mRNA}$ is preferentially expressed in neurons and epithelial cells in embryo and adult. Mech Dev 117:363367

6. Cave-Riant F, Denier C, Labauge P, Cécillon M, Maciazek J, Joutel A, Laberge-Le Couteulx S, Tournier-Lasserve E (2002) Spectrum and expression analysis of KRIT1 mutations in 121 consecutive and unrelated patients with cerebral cavernous malformations. Eur J Hum Genet 10:733-740 